\title{
Revisiting inter-organizational relational dynamics framework: Applying TOPSIS analysis on power and satisfaction through eight supply chains cases
}

\author{
Iskander Zouaghi ${ }^{\mathrm{a}}$, Abderrazak Laghouag ${ }^{\mathrm{b} *}$, Angappa Gunasekaranc ${ }^{\mathrm{c}}$, V. Raja Sreedharan ${ }^{\mathrm{d}}$, Tarik \\ Saikouk $^{\mathrm{e}}$, Mohammad Alqahtani ${ }^{\mathrm{b}}$ and Waleed Essayed ${ }^{\mathrm{b}}$
}

${ }^{a}$ Department of Industrial Engineering, Polytechnic National School, Algiers, Algeria

${ }^{b}$ Department of Business Administration, King Khalid University, Saudi Arabia

${ }^{c}$ School of Business Administration, Penn State Harrisburg, United States

${ }^{d}$ BEAR Lab, Rabat Business School, International University of Rabat, Morocco

eExcelia Business School, CERIIM, La Rochelle, France

\section{A B S T R A C T}

\section{Article history:}

Received October 16, 2021

Received in revised format

October 30, 2021

Accepted December 212021

Available online

December 212021

Keywords:

Inter-Organizational

Relationships

Supply Chain Dynamics

Social Exchange Theory
Lots of work has been conducted to explore and explain inter-organizational relations between supply chain partners. However, we have noticed that there is no accurate agreement between authors. Therefore, to better understand this disparity, the authors have studied supply chain interorganizational relationship dynamics in different industries to bring out an analytical framework that allows a better understanding of such an issue. Further, the framework is subjected to expert's opinion and ranked using the Technique for Order of Preference by Similarity to Ideal Solution (TOPSIS) approach. These case studies instruct professionals and researchers so that they bring up their level of abstraction that remains appropriate to catch this dynamic in order to guide decision-making and future research and studies.

\section{Introduction}

Nowadays claim a relative adequacy between supply and demand, it is needed to adopt a forward-thinking of integration of relevant generating value processes and activities among all players in the supply chain (Lambert and Cooper, 2000; Huang et al., 2014), while maintaining agility, adaptability, and alignment between their different interests (Lee et al., 2000; Lee, 2004). In this way, supply chain can be defined as a hierarchical, dynamic, and process-oriented network, consisting of a set of autonomous companies (from the first supplier to the end customer), linked by upstream and downstream flows (physical, informational, financial and knowledge) and driven by different level relationships, established in order to satisfy customers through better coordination and integration, but also by means of greater flexibility and responsiveness (Zouaghi et al., 2010). These supply chains can be presented as unavoidable phenomena arising from a need for coordination and flexibility among a set of companies. In this sense, supply chains exist, whether managed or not (Mentzer et al., 2001; Min et al., 2008). So, collaboration in these organizational configurations can be defined as the ability to work across organizational boundaries as a single entity (Sanders, 2011) to build and manage unique value-added processes to better meet customer needs (Fawcett et al., 2008; Fawcett et al., 2012; Cao \& Zhang, 2013). Behavioral operations management (Chen et al., 2012), or we can also call it behavioral supply chain management (Tokar, 2010; Siemen, 2011; Tangpong et al., 2013; Fahimnia et al., 2019), is about to be distinguished in new trends. Behavioral operations can provide insight into how to improve operational settings and policies considering behavioral tendencies by better understanding what these individuals do and why (Donohue et al., 2018). Basically, two main aspects describe management and decisions in supply chains. The first one is technical-oriented, which include mainly engineering, economic and financial domains, namely those that use rational objective reasoning to * Corresponding author

E-mail address: alaghouag@kku.edu.sa (A. Laghouag)

(C) 2022 Growing Science Ltd. All rights reserved.

doi: $10.5267 /$ j.uscm.2021.12.009 
solve emergent issues and inquiries. The second one is a social-oriented aspect that includes essentially social and psychological domains when exchanging with others. For the latter, Klassen and Vereecke (2012) stress that supply chain management has left social concerns last. They add the fact that lots of pioneering companies find difficulties to define, understand and plan for social issues. Yawar and Seuring (2019) add that managing social issues in supply chains improves the economic as well as sustainability performance of the buyers and suppliers. Accordingly, we have noticed that one of the main factors that drive companies to marginalize management of social aspects of relations with their supply chain partners, in a structured and justified manner, is the struggle to assume relevant inter-organizational relational variables and the dynamics governing them. Indeed, Power (2005), quoting Handfield and Nichols (1999), underline the fact that the technological and physical transfer elements are understood, and that the issue of relationships is more difficult, less well understood and therefore more fundamentally important for the effective management of supply chains.

This issue is even more important that the partners of a supply chain are still evolving using bipolar strategies, including cooperation and competition (Zouaghi et al., 2010). Even more, in a supply chain positioning, both cooperation and competition are essential, because they coexist in an ago-antagonistic system dynamic (Zouaghi \& Spalanzani, 2011). Moreover, the fact that the supply chain embodies a dynamic network, makes it more exposed to variations and instabilities giving rise to conflicts or opportunistic behaviors, because of the uncertainty and ambiguity of situations. But unexpectedly, some altruistic behavior can emerge from some partners aiming at quite idiosyncratic goals. In this sense, the Social Exchange Theory (SET) can better elucidate this phenomenon. So, in this paper, the authors have reviewed the social exchange theory. This will allow us to better introduce our concepts to come up with a framework that elucidates supply chain relational dynamics within this paradigm. Then, we present our methodology, namely a multiple-case methodology including cases selection and data collection protocol followed by testing using the TOPSIS approach. Followed with a discussion, and finally conclude and provide further research trends.

\section{Literature review}

Initiated by authors like Blau (1964), the Social Exchange Theory (SET) represents a theoretical corpus, which argues that individuals or organizations are in a social exchange logic looking for rewards and benefits, and avoiding punishment (Emerson, 1976). SET is a very broad conceptual framework that has proven itself capable of describing almost any reasonable pattern of findings, at least in a post hoc manner (Cropanzani et al., 2017). In this way, companies establish relationships with others to warrant mutual advantages. Thus, in contrast to economic exchange theory, which defines an actor as a homo-economicus, which is rational egoist, utilitarian and hedonistic, the SET highlights the fact that this actor is also characterized by altruism, social values and even subjectivism. Blau (1964) specifies that the SET is characterized by indefinite individual engagement and trust such as intrinsic rewards, hence situated between rational calculation of gain and pure affective behavior. Moreover, social exchange theory insists more on ensuring long-term social relations, than on a short-term transaction in the marketplace. Furthermore, in a SET approach, future actions and behaviors are conditioned by former ones. In this sense, the more beneficial the result of a member's action, the more likely this one is to perform the action again (Blau, 1964). So, when a partner does not receive an expected benefit or incurs an unpredicted punishment, will behave negatively in future actions (Homans, 1961). These benefits are not fixed with a rational calculation; they are evaluated compared to a certain number of quantitative and qualitative elements, which generally cannot be easily determined. So, it's difficult to evaluate them on a transaction approach basis (Masterson, 2000). For the SET proponents, power is seen as a significant factor that interferes within a relationship. Power has been defined as the ability of a member to influence or to control the decisions and the behavior of other members (Friedberg, 2009). But relational attitudes and behaviors are conditioned by the perceived justice established by the more powerful member of the exchange and that the enactment of such policies allows the member to retain and protect its power (Griffith et al., 2006). These elements stimulate the nature of the relationship between members that will guide the future exchange.

\section{Supply chain relational dynamics: Conceptual frameworks}

When reviewing the most relevant literature that intervene within a supply chain, what stands out first is the tiered relationship between different actors and their corresponding influence, namely the power they have (Cox, 1999; Benton \& Maloni, 2005). The exercise of this power creates an instinctive reaction of the one who undergoes it, resulting in a level of satisfaction (Benton \& Maloni, 2005). This level of satisfaction presents, therefore, a second major factor and has a direct impact on the nature of the relationship (conflict, cooperation, coordination, collaboration) between different supply chain actors, which also depends on trust, commitment of actors and interdependencies between their different processes (Mohr \& Spekman, 1994; Mentzer et al., 2001). Indeed, Nakandala et al. (2020) states that balanced power relationships in the supply chain accept reasonable power to sit in product price determination irrespective of the dependency of small-scale companies on relatively large local retailers. Finally, the relational antecedents determine the degree of information sharing (Patnayakuni et al., 2006), which presents another factor in this relational dynamic. On this basis, these factors will be detailed and analyzed in order to constitute a framework explaining the relationship dynamics that governs the supply chain. 


\subsection{Power and satisfaction}

One of the most used definitions of power is that of Dahl (1957, p.290). He stipulates "A has power over B to the extent that he can get B to do something that B would not otherwise do". Also, cited by Friedberg (2009), Crozier (1970) defines "the power of an actor A as its ability to impose on an actor B term of trade that are beneficial to him". So power is a relative force, justified or not, a player can have on another within a given relationship. For Benton and Maloni (2005), the power plays a decisive role in the supply chain. It allows the determination of relational influences between actors, especially since the identification of its sources shows that it can have a varied effect on inter-organizational relationships but also on the behavior of each actor. In other terms, power dynamics shape partnerships (Chicksand, 2015). Moreover, the power allows the hierarchy of structural dominance, defined by Cox (1999) as situations in which there are one or several dominant players, who can capture or control the key resources that generate value. In the same vein, Munson et al. (1999) state that a player has the power in a supply chain if he is in possession of a strong market position, he has access to a major part of financial resources; he has access to important or critical information or he has an irreplaceable position. They add that the exercise of power within the supply chain revolves around price, inventory, operations, channel structure, and information controls. Moreover, the typology of French and Raven (1959) identifies five sources of power: reward, coercion, legitimacy, reference and expertise. Another source added by Raven (1959), which is information. However, Hunt and Nevin (1974) classify power in coercive and non-coercive power. Molm (1997) states that this classification is more relevant because the other four sources of power determined by French and Raven (1959) (reward, legitimacy, reference and expertise), considered as non-coercive, include benefits of the promotion of desired behaviors while the coercive power source is mainly based on the exercise of force. Consequently, this latter type will be taken into account in our research, since it is sufficient to distinguish the behaviors in a supply chain. This has been studied before by Beier and Stern (1969), who found that non-coercive power is an alternative which can increase satisfaction for the weakest members. Consequently, the latter type will be taken into account in our research, since it is sufficient to distinguish behaviors in the supply chain. Even so, the typology of French and Raven (1959) updated by Raven (1964) may provide some explanation, since it allows us to have more information on the sources of power. In a more accentuated approach, Gölgeci et al. (2018) distinguish three power-based behaviors, namely dominance, egalitarian, and submissive.

The exercise of power by an actor on one or more other players, whatever its source, is not without consequences. In other words, the exercise of power in a coercive logic does not have the same echo. Thus, the satisfaction of partners presents a major factor in building relationships and making decisions in the supply chain. Anderson and Narus (1990) defined satisfaction as a positive emotional state resulting from the evaluation of all aspects of the relationship between a company and its partner. Through our research, we adopt the definition of Benton and Maloni (2005), which stipulate that partner satisfaction is a feeling of fairness in the relationship whatever existing power imbalance. In this way, the work of Benton and Maloni (2005) shows that the coercive power (reward, coercion and legitimacy) has a negative impact on the satisfaction of the partner who undergoes it. By cons, non-coercive power (reference, expertise and information) has a positive impact on the level of satisfaction of the same partner. Indeed, Gölgeci et al. (2018) suggest that rather, relational satisfaction is experienced by both supply chain partners, revealed in sharing promising sentiment toward one another and with each valuing the relationship. Hunt and Nevin (1974) outlined six main benefits arising from the satisfaction of the partner that undergoes power. When satisfied, this partner has a high level of morale, cooperates better, avoids deliberately terminating contracts, is less likely to file individual or class action suits against who has the power and is less likely to seek protective legislation. Therefore, partners' satisfaction greatly improves the relationship between them. So, we can say that the level of satisfaction has a greater or lesser impact on the nature of the relationship that binds the different actors. In this line, quoted by Benton and Maloni (2005), Guneshan and Harrison (1997) showed that the level of satisfaction represents a significant factor in the performance of long-term relationships. Similarly, Skinner et al. (1992) have demonstrated that the level of satisfaction has a positive relationship with cooperation, and a negative relationship with conflict.

\subsection{Trust, commitment and interdependence}

Trust can be described as a belief that the company would accomplish only actions that will yield positive results (Anderson \& Narus, 1990). This trust arises when one party believes in the reliability and the integrity of its exchange partner (Morgan \& Hunt, 1994). For Högberg (2002), this trust is gradually developed with the gradual deepening of the relationship through a process of mutual adaptation, although not necessarily in a symmetrical manner, to the needs of the other partner. Likewise, commitment is defined as an implicit or explicit pledge on the continuity of exchange between partners (Dwyer et al., 1987). By relating these concepts Morgan and Hunt (1994), state that a company can expand cooperation by increasing trust and commitment. However, trust has a major influence on the players' commitment in the relationship (Achrol, 1991; Ruyter et al., 2001). Nakandala et al. (2020) underlined that trust-based relationships are developed over multiple transactions, where shared values across the supply chain and consistently low opportunistic behavior in reward sharing are demonstrated to be the crucial factors underpinning close relationships. Power (2005) argument that the necessity for trust, open communication and the interdependence of distinctive components of the supply chain as technology implementations bridge company boundaries has thrown further emphasis on the importance of such cooperative strategies (Power, 2005). 
In the same line of Kambil and Short (1994), Kumar and van Dissel (1996) state that the interdependence in the sense of Thompson (1967), determines the level of relations between the different actors. The levels of interdependence, namely pooled interdependence, sequential interdependence and mutual one, as they have been determined by Thompson (1967), have a greater or lesser extent on the level of relations between actors.

\subsection{Tolerance and altruism}

As we have seen before, SET includes in inter-organizational behavior objectivism and subjectivism, but also both opportunism and rigor, and altruism and tolerance. Autry et al. (2008) stipulate that these last behaviors reproduce an effort to help and support supply chain partners facing business issues or provide them with knowledge that they will assume themselves. These authors add the fact that tolerance presents the willingness to accept inconveniences when performing business with partners, such as a decrease in performance, impositions on the focal firm coming from inevitable externalities, and other inconveniences relative to cooperating with partners. They also underline the fact that inter-organizational tolerance comprises the allowance of such inconveniences without penalty or sentence. Moreover, Ge and Hu (2012) have studied through game theory, companies' altruistic motivations in supply chains. They demonstrate that supply chain performance relative to altruism remains among situations depending on decentralization and integration. They also show besides that a manufacturer, as a leader, should bargain with an egoistic retailer, while a retailer, as a follower, should deal with a manufacturer with altruistic liability, to ensure performance. Autry et al. (2008) operationalize these concepts under the interorganizational citizenship behaviors (ICB's). They define it as an interfirm behavioral tactics, generally enacted by boundary personnel, that are discretionary, not directly or explicitly included in formal agreements, and that in the aggregate promote the effective functioning of the supply chain (Autry et al., 2008, p. 54).

\subsection{Inter-organizational relationship nature}

Thereby, we can say that within a supply chain, the nature and intensity of the relationship that links the different actors can be approached with a dichotomous logic. Indeed, either the factors that influence this relationship are positive leading to an agreement position, which can result in cooperation, coordination or collaboration. Or, they are relatively hostile, and here companies are facing a situation of conflict and opposition. Cited by Fawcett et al. (2008), Parker and Anderson (2002) show that nature of inter-firm collaboration can be the cause of many barriers to collaboration. In supply chains, conflicts can arise between partners from differences relative to certain elements. Hocker and Wilmot (1985) defined the conflict as a disagreement expressed between at least two interdependent parties who perceive incompatible goals, poor rewards and interference of the other party in achieving their goals (mutual). These conflicts can arise from a difference of power, competition for scarce resources, a tendency to differentiate a negative interdependence between entities, an ambiguity about the legal responsibility or authority, a deterioration of the image of one of them or its value (Deutsch, 1969). Being in conflict, members of a supply chain tend naturally to a local optimization to the detriment of the overall performance of the chain. To address this, members of a supply chain cooperate, coordinate, or collaborate in the sense of common interest. Moreover, supply chain integration depends, among others, of organizational factors such as trust, commitment, interdependence, organizational compatibility, vision, core processes, leadership, and support of top management (Mentzer et al., 2001). Thus, we can say that in addition to previously invoked satisfaction level, trust, commitment and interdependence are critical determinants of the relationship nature between different partners (Mohr \& Spekman, 1994).

\subsection{Information sharing}

At the supply chain level, information is critical to coordination and flow optimization. Retention or bad reporting can cause distortion and loss of visibility; and thus, amplifying the Bullwhip effect (Lee et al., 1997) and decreasing the supply chain performance. Furthermore, it should be noted that the fact of sharing information between companies has an impact on performance (Lee et al., 2000) depends on a better consideration of the antecedents of this sharing (Samaddar et al., 2006). That said, Patnayakuni et al. (2006), shows that information sharing is influenced by previous relationships, then the nature of relationships that link the various players in the supply chain. Through inter-organizational setting, three situations of sharing can be presented, namely a situation where no information is shared, a situation where certain information is shared and a final in which nearly all information is shared (Gavirneni et al., 1999). Moreover, the degree of information sharing also depends on two key elements, namely the information quality and the cost that allows access to it. Zhou and Benton (2007) state that the quality of information shows the degree to which the information exchanged between companies coincides with their needs. The quality of information is determined by its completeness, accuracy (the absence of noise), its reliability, smoothness and accuracy, timeliness, punctuality, its shape and richness, and finally to its accessibility (Reix, 2004). This quality is desired just for the cost that allows its availability. If the cost of information is too high some quality criterion can be set aside. Therefore, before sharing information, members of a supply chain evaluate the quality/cost ratio in a precise or approximate manner. Consequently, this ratio has a direct impact on the degree of information sharing between different supply chain partners. 


\section{Multiple-case study methodology: Cases assortment and data collection}

In order to understand the complex phenomena, such as inter-organizational relational dynamics between companies within a supply chain, requires an in-depth study methodology. Thus, we opted for a qualitative methodology because, as mentioned by Danzin and Lincoln (2008, 2011), "it uses semiotics, narrative, content, discourse, archival and phonemic analysis", and in our case, we need to explore all information and knowledge resulting from these kinds of analysis, to go beyond what is really perceived by quantitative studies. Subsequently, we have selected case study methodology or more precisely multiplecase study methodology in order to explore similarities and differences within and between cases, and to capitalize trough replicating findings by means of cases. So, it is important that these cases are overflown carefully so that the researcher can identify analogous results crosswise, or contrast results based on existing theory (Yin, 2008). Thus, it should be noted that each case has to be studied separately, but the main interest lies in the collection of these cases or in the issue displayed in these cases (Stake, 2006).

\subsection{Cases identification and selection}

Case identification and selection is an important step in multiple-case studies in particular. Flyvbjerg (2011) identifies six case selection strategies, and has classified them in two main classes, namely random selection strategies and informationoriented selection strategies. In our work, we adopt the maximum variation cases strategy, which represents an informationoriented selection. Flyvbjerg (2011) specifies that this strategy is used to obtain information about the implication of numerous circumstances or settings for case process and outcome. He gives examples of some dimensions like the size, the organization form, location and budget. In our instance, we select our cases depending on six variable dimensions, namely product (simple to complex) and manufacturing system (mass to customized production) characteristics, systemic and environmental uncertainty (deterministic to chaotic), strategic position in economy, and legal and governmental influence. We have selected 8 cases, each one in a specific industry, namely, retail industry, Para chemical industry, automotive industry, agri-food industry, sporting goods industry, aerospace industry, toy industry and luxury industry.

\subsection{Data collection}

As we have mentioned above, one of the characteristics of qualitative methodologies is the fact that we can use plenty of information sources, such as narrative information, discourses reports, archives, internal and external documents, and so on. In this respect, Yin (2008) stipulates that multiple-case study exploits multiple sources of evidence for assessment. Thus, in our research we used information from three major sources, namely internal documents (flow charts, internal notes and reports, ...), external reports (companies' websites, consulting and experts' reports, ...), and Semi-structured interviews (Supply chain managers, Logistics leaders, ...) followed by ranking using TOPSIS approach.

\subsubsection{Internal documents and external reports}

Depending on companies studied, the diffusivity and the accessibility to their materials, internal documents providing information on their operations, logistics and supply chain system, and others enlightening their activities were exploited to understand their formal functioning. Also, external reports were used to have an outside view on these companies, but also to have more accurate information about their industry structure and their positioning inside. All these documents were also used to analyze our cases after having done semi-structured interviews.

\subsubsection{Semi-structured interviews}

To reach our goal, which is the understanding of a complex phenomenon, but at the same time staying in a specified area of conceptual framework, semi-structured interviews were conducted depending on a predetermined interview protocol, specifying the main elements covered with an open part. We chose the semi-structured interviews to provide both flexibility, which cannot be allowed by structured interviews, and focus that can hardly be guaranteed through an open interview. Interviews were conducted with persons that were the most concerned with our issue. Supply chain, operations and logistics managers and other competent people were interviewed face-to-face or by telephone. These interviews were transcribed and analyzed in terms of our conceptual framework. Further, to understand the influence of the social capital on various organizations, the expert was requested to rate their preferences for various attributes of the conceptual framework using the TOPSIS approach. This approach highlighted the influence of the supply chain dynamics in different industries. As mentioned in section 4.2 the eight decision makers were chosen based on their expertise and experience from each industry. The decision makers were asked to evaluate the factors where 0 denotes no Influence and 5 denotes high influence. Based on the experts rating the researcher used the TOPSIS approach to test the rank for each factor in the conceptual model as in the Fig. 1. According to Sarkar (2013) TOPSIS approach helps in deriving the best outcome from alternatives using the rating from the decision maker. Based on the TOPSIS approach, one of the factors from the supply chain dynamics factor is chosen and ranked in the eight industries using the experts rating.

Step 1: Creating a matrix to tabulate the ratings and weight for each factor and evaluating using equation Eq (1). 


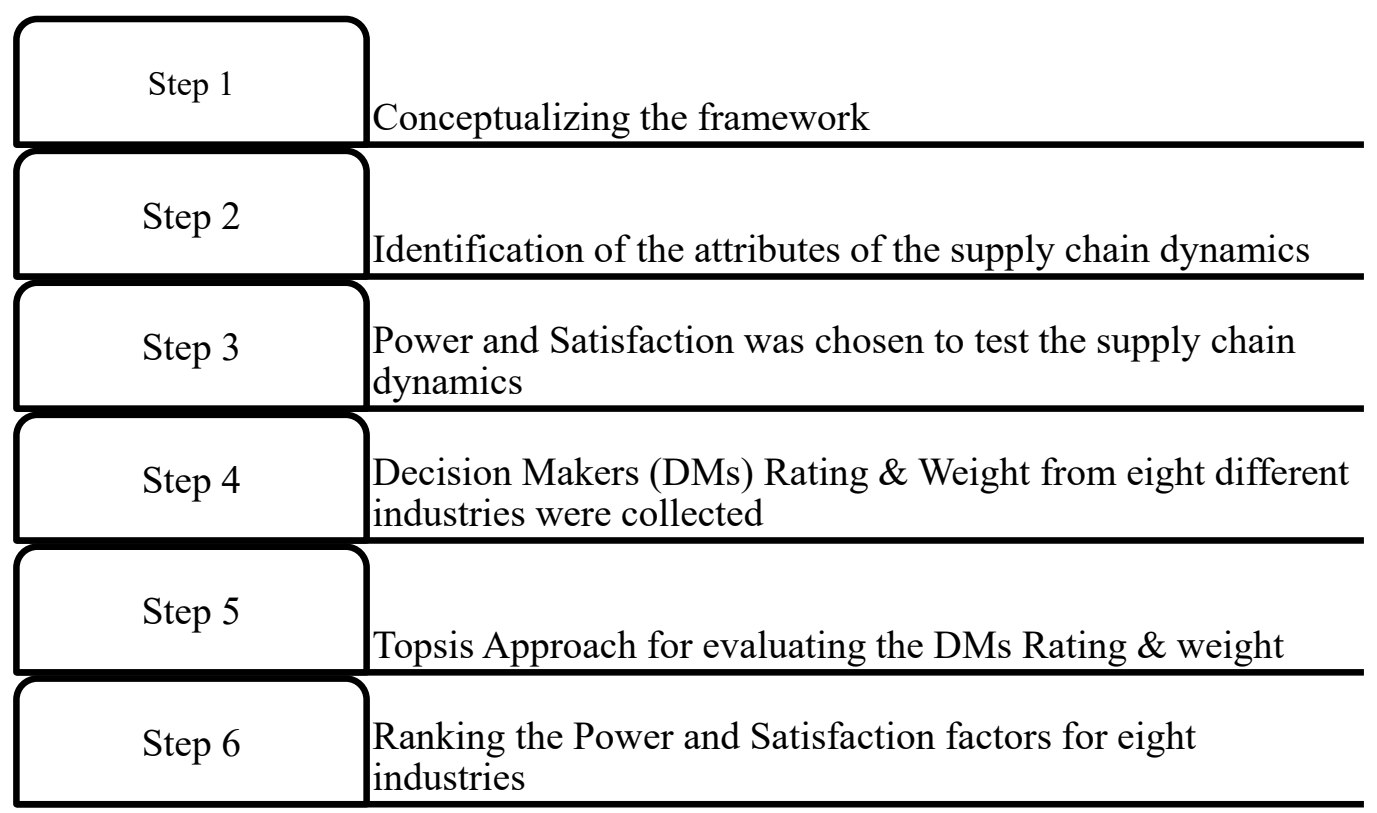

Fig. 1. Ranking the attributes of the supply chain dynamics

$$
\begin{aligned}
\text { Matrix } & =\left[\begin{array}{ccccc}
X 1.1 & \ldots & X 1 . j & \ldots & X 1 . n \\
X 2.1 & \ldots & X 2 . j & \ldots & X 2 . n \\
\vdots & \vdots & \vdots & \vdots & \vdots \\
X i .1 & \ldots & X i . j & \ldots & X i . n \\
\vdots & \vdots & \vdots & \vdots & \vdots \\
X X_{X .1} & \ldots & X m . j & \ldots & X m . n
\end{array}\right] \\
\mathrm{R}_{\mathrm{ij}} & =\frac{X i j}{\sqrt{\sum_{i=1}^{m} X i j^{2}}}
\end{aligned}
$$

where, $\mathrm{i}$ is the score index, $\mathrm{j}$ is the supply dynamics factor index, $\mathrm{n}$ rating criteria used

Step 2: The weighted decision matrix is constructed by multiplying each rating from the experts with their weightage for each factor (refer Eq. (2)).

$$
V_{i j}=W_{j} \times R_{i j}
$$

Step 3: The next step is the Identification of the $\mathrm{A}^{+}$and $\mathrm{A}^{-}$-Ideal Points. In this stage, maximum and minimum values for each column in a weighted matrix are determined.

$$
\begin{aligned}
& \mathrm{A}+=\left\{\mathrm{V}^{+}{ }_{1}, \mathrm{~V}^{+}{ }_{2}, \ldots, \mathrm{V}^{+}, \ldots, \mathrm{V}^{+}{ }_{\mathrm{n}}\right\} \text { (maximum values) } \\
& \mathrm{A}-=\left\{\mathrm{V}^{-}, \mathrm{V}^{-}{ }_{2}, \ldots, \mathrm{V}_{\mathrm{j}}^{-}, \ldots, \mathrm{V}_{\mathrm{n}}^{-}\right\} \text {(minimum values) }
\end{aligned}
$$

Step 4: The distance of each element from the positive ideal solution $\left(\mathrm{S}^{+}{ }_{\mathrm{i}}\right)$ and negative ideal solution $\left(\mathrm{S}_{\mathrm{i}}^{-}\right)$is calculated using the Eq. (3) and Eq. (4).

$$
S_{i}^{+}=\sqrt{\sum_{j=1}^{n}\left(V i j-V^{+} j\right)^{2}}
$$




$$
S_{i}^{-}=\sqrt{\sum_{j=1}^{n}\left(V i j-V^{-} j\right)^{2}}, i=1, \ldots, m
$$

Step 5: The relative closeness of the CFFs $\left(\mathrm{S}_{\mathrm{i}}\right)$ is calculated. The relative closeness is considered as the ranking score which is used to rank the alternatives as in Eq. (5).

$$
S_{i}=\frac{S_{i}^{-}}{S_{i}^{+}+S_{i}^{-}}, i=1, \ldots, m
$$

Based on the step 5 the rank for the power and satisfaction factor is calculated for the 8 industries and tabulated in Table 1 .

Table 1

Power and satisfaction with the eight Industries

\begin{tabular}{llll}
\hline S.no & Power and satisfaction & Ci & \multicolumn{1}{c}{ Rank } \\
\hline 1 & Retail & 0.8176 & 1 \\
2 & Para-chemical & 0.7373 & 3 \\
3 & Automotive & 0.7238 & 4 \\
4 & Aerospace & 0.6076 & 5 \\
5 & Agri-food & 0.5591 & 6 \\
6 & Sporting & 0.5469 & 7 \\
7 & Luxury & 0.5427 & 8 \\
\hline
\end{tabular}

Similarly, other factors can be tested for the eight industries to understand its preference in the industries by the experts. Retail industries have the most influence with the first rank $(0.8176)$ followed by para- chemical $(0.7373)$ and however, the toy industries have the least affinity $(0.4481)$. Furthermore, the authors have identified the expert's preference from interview and tabulated in Table 2.

\section{Results and Discussion}

To meet scientific expectations and rigor of qualitative research, and specifically multiple-case studies, we explore correspondences and differences within and between our 8 cases, to build knowledge by replicating results. By referring to Table1, we can see first that relational characteristics differ depending on the industry. In most of the supply chains studied, power is non-coercive, and is in most industries (4/8) expert and/or legitimate. So, in the retail industry, automotive industry, agri-food industry and toy industry, power is mostly based on the expertise and capabilities of the focal company or on its legitimacy. We have also noticed that power can be leveraged from the Group to which belongs the focal company, as in aerospace industry, or can be based to availability or access to raw materials, as for the luxury industry. Likewise, we can notice that power of the focal companies can be based on market-oriented sources, such as for the sporting industry in which we have found that power is based mostly on the percentage of market share. We can see for some power sources that Munson et al. (1999) has mentioned some of the power sources in a supply chain, which are the possession of a strong market position, and access to a major part of financial resources.

When analyzing satisfaction, we can advance the fact that there is satisfaction for an input like developing capabilities and knowledge in aerospace, automotive and Para chemical industries, or satisfaction for an output like volume orders in toy industry, or referencing in the retail industry. Analytically, we can say that the angle chosen in the literature, cf. Benton and Maloni (2005), to consider the fact that power is coercive or not, can mislead us because we found in our study that a partner can be satisfied even if power of the focal company is coercive. Therefore, we think that approaching satisfaction is better fecund when dealing with its stance (input or output). Examination of our cases allows us to see that trust and commitment are interdependent concepts, and that commitment aspect follows generally trust facts. For most supply chains, trust is cognitive and based on several elements. For example, in automotive, aerospace, sporting and toy industries, trust is based on competencies, innovation and research capabilities of partners. In agri-food and luxury industries, it depends mostly on network and partnership period. In the retail industry it depends on the share of the partner in the turnover, and in the sporting industry, in addition to competencies, it depends on the brand of the partner. For commitment, most industries move towards SLAs, openness to auditing or simple performance objectives. 
Table 2

Supply chain dynamics with the eight industries

\begin{tabular}{|c|c|c|c|c|c|c|c|c|}
\hline Factors & Case 1: Retail & Case 2: Para-chemical & Case 3: Automotive & Case 4: Aerospace & Case 5: Agri-food & Case 6: Sporting & Case 7: Luxury & Case 8: Toy \\
\hline $\begin{array}{l}\text { Power and } \\
\text { satisfaction }\end{array}$ & $\begin{array}{l}\text { Power based on } \\
\text { mastering of transport } \\
\text { solutions and goods } \\
\text { distribution and } \\
\text { suppliers referencing. }\end{array}$ & $\begin{array}{l}\text { Coercive power. } \\
\text { Satisfaction assessed } \\
\text { trough } 13 \text { criterions } \\
\text { including } 4 \text { aspects: } \\
\text { purchasing, }\end{array}$ & $\begin{array}{l}\text { Expert and legitimate } \\
\text { power. Importance of } \\
\text { satisfaction for } \\
\text { advancement and } \\
\text { development }\end{array}$ & $\begin{array}{l}\text { Power leveraged from the } \\
\text { Group. Capability and } \\
\text { knowledge-based } \\
\text { satisfaction. }\end{array}$ & $\begin{array}{l}\text { Expert and } \\
\text { legitimate power } \\
\text { (supervisor) }\end{array}$ & $\begin{array}{l}\text { Non coercive power } \\
\text { based on percentage } \\
\text { of market share }\end{array}$ & $\begin{array}{l}\text { Non coercive } \\
\text { power based on } \\
\text { availability of } \\
\text { raw materials. }\end{array}$ & $\begin{array}{l}\text { Expert power of } \\
\text { leaders. Satisfaction } \\
\text { is based on volume } \\
\text { of orders. }\end{array}$ \\
\hline $\begin{array}{l}\text { Trust and } \\
\text { commitment }\end{array}$ & $\begin{array}{l}\text { Depends principally } \\
\text { on the share of a } \\
\text { partner in the } \\
\text { turnover. }\end{array}$ & $\begin{array}{l}\text { Mutual trust and } \\
\text { SLA(Service Level } \\
\text { Agreement) for } \\
\text { commitment }\end{array}$ & $\begin{array}{l}\text { Cognitive trust is based on } \\
\text { competencies. It depends } \\
\text { also on countries and } \\
\text { importers characteristics. }\end{array}$ & $\begin{array}{l}\text { Trust based mostly on } \\
\text { closeness to government } \\
\text { and army, and research }\end{array}$ & $\begin{array}{l}\text { Partnership period- } \\
\text { based trust. }\end{array}$ & $\begin{array}{l}\text { Brand and technical } \\
\text { based trust. } \\
\text { Suppliers' seniority }\end{array}$ & $\begin{array}{l}\text { Network based } \\
\text { trust, and quality } \\
\text { and lead-time } \\
\text { commitment }\end{array}$ & $\begin{array}{l}\text { Cognitive trust } \\
\text { based on quality } \\
\text { and norms } \\
\text { respect. }\end{array}$ \\
\hline $\begin{array}{l}\text { (Inter) } \\
\text { dependence }\end{array}$ & $\begin{array}{l}\text { One supplier per } \\
\text { product and one } \\
\text { supplier of aid. }\end{array}$ & $\begin{array}{l}\text { Interdependence due to } \\
\text { hyper competitive } \\
\text { market and context }\end{array}$ & $\begin{array}{l}\text { Depends mostly on } \\
\text { technological concerns. } \\
\text { Interdependent with OEMs } \\
\text { (Original Equipment } \\
\text { Manufacturers) and } \\
\text { dependence of } \\
\text { subcontractors. }\end{array}$ & $\begin{array}{l}\text { Suppliers' capability } \\
\text { dependence. Materials and } \\
\text { components based inter- } \\
\text { dependence. Government } \\
\text { and army specifications } \\
\text { dependence. }\end{array}$ & $\begin{array}{l}\text { Dependence of the } \\
\text { focal company due } \\
\text { to material } \\
\text { investments and } \\
\text { products }\end{array}$ & $\begin{array}{l}\text { Activities and } \\
\text { operations depend } \\
\text { on the Group } \\
\text { orientation. }\end{array}$ & $\begin{array}{l}\text { Perenity and } \\
\text { brand-based } \\
\text { interdependence. }\end{array}$ & $\begin{array}{l}\text { Majorly depends } \\
\text { on distributors } \\
\text { and retailers. } \\
\text { Developing } \\
\text { exclusiveness in } \\
\text { global market. }\end{array}$ \\
\hline $\begin{array}{l}\text { Tolerance and } \\
\text { altruism }\end{array}$ & $\begin{array}{l}\text { Benefited small local } \\
\text { producers and those } \\
\text { who manufacture } \\
\text { local products }\end{array}$ & Problem dependent & $\begin{array}{l}\text { Little tolerant and altruistic } \\
\text { due to the size and the } \\
\text { complexity of the } \\
\text { organization. }\end{array}$ & $\begin{array}{l}\text { Supporting partners in all } \\
\text { kinds of problems. }\end{array}$ & $\begin{array}{l}\text { Especially with } \\
\text { small producers who } \\
\text { wants to convert to } \\
\text { fair trade (solidarity). }\end{array}$ & $\begin{array}{l}\text { Establishing poles } \\
\text { to guide suppliers } \\
\text { and help them }\end{array}$ & $\begin{array}{l}\text { Closeness and } \\
\text { consensus-based } \\
\text { tolerance. }\end{array}$ & $\begin{array}{l}\text { Enlarging the } \\
\text { variety of product } \\
\text { depending on } \\
\text { trust. }\end{array}$ \\
\hline $\begin{array}{l}\text { Inter- } \\
\text { organizational } \\
\text { relationship } \\
\text { nature }\end{array}$ & $\begin{array}{l}\text { Lean management } \\
\text { and cooperation } \\
\text { trough distribution } \\
\text { centers. Managing } \\
\text { conflict through a } \\
\text { movement }\end{array}$ & $\begin{array}{l}\text { Synchronous flow } \\
\text { management through } \\
\text { excellence centers. } \\
\text { Managing conflict } \\
\text { through negotiation. }\end{array}$ & $\begin{array}{l}\text { Synchronous flow } \\
\text { management across } \\
\text { geographical promiscuity. } \\
\text { Conflicts depend on the } \\
\text { heaviness of problems } \\
\text { chronicity. }\end{array}$ & $\begin{array}{l}\text { Partners can work within } \\
\text { the production site of the } \\
\text { focal firm. Little conflicts. } \\
\text { Conflicts are generally } \\
\text { solved by financial } \\
\text { penalties }\end{array}$ & $\begin{array}{l}\text { A business } \\
\text { cooperative system } \\
\text { of management. } \\
\text { Little conflict } \\
\text { (mainly concerns } \\
\text { quality and delivery } \\
\text { time) }\end{array}$ & $\begin{array}{l}\text { Collaboration based } \\
\text { on research and } \\
\text { innovation. Lean } \\
\text { operations } \\
\text { management } \\
\text { approach. }\end{array}$ & $\begin{array}{l}\text { Activities are } \\
\text { centralized and } \\
\text { collaboration } \\
\text { with supplier is } \\
\text { close on behalf } \\
\text { of reactivity. } \\
\text { Conflicts are } \\
\text { insignificant. }\end{array}$ & $\begin{array}{l}\text { Coordination } \\
\text { through purchase } \\
\text { centers and } \\
\text { collaboration } \\
\text { through relocated } \\
\text { offices. Conflicts } \\
\text { are rare }\end{array}$ \\
\hline $\begin{array}{l}\text { Information } \\
\text { sharing }\end{array}$ & $\begin{array}{l}\text { Operational and } \\
\text { control information is } \\
\text { shared. ERP systems } \\
\text { are used. }\end{array}$ & $\begin{array}{l}\text { Performance and } \\
\text { control information is } \\
\text { shared. Open for } \\
\text { proposed solutions to } \\
\text { improve reliability and } \\
\text { quality of service }\end{array}$ & $\begin{array}{l}\text { Real time tracking through } \\
\text { EDI and SRM (Supplier } \\
\text { Relationship Management) } \\
\text { System. }\end{array}$ & $\begin{array}{l}\text { Depends majorly on the } \\
\text { partner (civil or military). } \\
\text { Generally use an ERP } \\
\text { system (SAP), and EDI. }\end{array}$ & $\begin{array}{l}\text { Operational } \\
\text { information is shared } \\
\text { through ERP and } \\
\text { tractability systems. } \\
\text { WMS (Warehouse } \\
\text { Management } \\
\text { System) and e- } \\
\text { marketplaces }\end{array}$ & $\begin{array}{l}\text { Deployment of } \\
\text { CAPM (Computer- } \\
\text { Aided Production } \\
\text { Management), } \\
\text { ERP, WMS and } \\
\text { extranets for } \\
\text { communicating } \\
\text { majorly operational } \\
\text { information. }\end{array}$ & $\begin{array}{l}\text { All types of } \\
\text { information can } \\
\text { be shared for } \\
\text { satisfying } \\
\text { customer. }\end{array}$ & $\begin{array}{l}\text { Mainly sharing } \\
\text { operational } \\
\text { information, } \\
\text { namely orders via } \\
\text { EDI. }\end{array}$ \\
\hline
\end{tabular}


Dependence and interdependence between supply chain partners is seen as contingent to the number of partner determination, as in retail industry; or, to market complexity and competition level, as in Para chemical industry; or, to technological concerns like in automotive and aerospace industries; or else to product availability, like in agri-food; or on brand specificity and exclusiveness of a partner. We can also notice that dependence can be due to material investments and idiosyncrasy of products. For tolerance and altruism, it seems that most supply chains focal companies' on altruistic behavior and a high level of tolerance regarding small size of partners. We have noticed it in all retail, automotive, aerospace and agri-food industries. For supply chains in other industries, such as Para chemical and aerospace, tolerance and altruism are problem dependent (frequency and intensity). So, if the problem is not frequent and its impact is not important, the focal company will be tolerant and altruistic in helping its partner to overcome the problem. Also, when it comes to assisting suppliers for growth and enlarging the variety of product proposed, for respectively sport industry and toy industry, companies tend to be more tolerant and altruistic. When analyzing inter-organizational nature, we have noticed that in most supply chains, this nature depends on the flow management strategy of the focal company. For example, in retail, Para chemical, automotive, aerospace and sporting industries where lean and synchronous flow management strategies are adopted, focal companies are developing close collaborations with partners, and they manage conflicts through movements, negotiation and financial penalties. For the Agri-food industry, this nature depends on the structure of the focal company. In this case, it concerns a cooperative, so a lot of small companies cooperate depending on this structure. Finally, analysis of information sharing through cases shows that most information shared between supply chain partners concern operations, control and performance. We have also noticed that most supply chain partners use EDI, ERP and WMS systems and extranets in the supply chain context. All this can be consolidated in Table 3.

Table 3

Majors factors influencing supply chain relational dynamics

\begin{tabular}{|c|c|}
\hline & Major factors \\
\hline \multirow[t]{4}{*}{ Power } & Expertise and capabilities \\
\hline & Leveraged from the Group \\
\hline & Availability or access to raw materials \\
\hline & Percentage of market share \\
\hline \multirow[t]{2}{*}{ Satisfaction } & Satisfaction for an input like developing capabilities and knowledge \\
\hline & Satisfaction for an output like volume orders in toy industry or referencing \\
\hline \multirow[t]{4}{*}{ Trust } & Competencies, innovation and research capabilities \\
\hline & Network and partnership period. \\
\hline & Share of the partner in the turn over, \\
\hline & Brand of the partner \\
\hline \multirow[t]{3}{*}{ Commitment } & SLAs \\
\hline & Openness to auditing \\
\hline & Performance objectives \\
\hline \multirow[t]{6}{*}{ (Inter)dependence } & Number of partners \\
\hline & Market complexity and competition level \\
\hline & Product availability \\
\hline & Brand specificity \\
\hline & Exclusiveness of a partner \\
\hline & Material investments and idiosyncrasy of products \\
\hline \multirow[t]{3}{*}{ Tolerance and altruism } & Size of partners \\
\hline & Problem dependent (frequency and intensity) \\
\hline & Growth and enlarging variety of product proposed \\
\hline \multirow{2}{*}{$\begin{array}{l}\text { Inter-organizational relationship } \\
\text { nature }\end{array}$} & Depends on flow management strategy of the focal company \\
\hline & $\begin{array}{l}\text { Manage conflicts through movements, negotiation and financial penalties } \\
\text { Structure of the focal company }\end{array}$ \\
\hline \multirow[t]{2}{*}{ Information sharing } & Operations, control and performance. \\
\hline & EDI, ERP and WMS systems and extranets \\
\hline
\end{tabular}

\section{Conclusion}

The framework presented does not pretend to be complete, most important elements were highlighted to make the supply chain community aware of the importance of the social variables when apprehending supply chain issues. More specifically, this framework allows us to go through supply chain relational dynamics by underlining the importance of notions such as power, partner satisfaction, tolerance and altruism, the nature of inter-organizational relationships, trust, commitment, interdependence, and information sharing between supply chain members. Moreover, these variables are manifested in multiple ways depending on the industry. Nevertheless, like all research works, our framework presents several limitations. We can cite two main ones. The first is related to the conceptualization of the supply chain relational dynamic. Our conceptualization is quite specific to situations; as in some sectors and businesses, this dynamic remains dependent on the 
economic and technical guidance that governs inter-organizational relations. In these industries, companies integrate our framework as an optional element of decision making, avoiding, consequently, the risk of bias that may arise from the relationship. The second limitation is related to the lack of empirical validation for the proposed conceptual framework. Our reflection is based on previous research on the field but does not include any development on how these variables will be measured in a supply chain context. This can constitute a perspective for future research.

Information sharing presents one of the responses that permit mitigating the bullwhip effect is between supply chain members. Supply chain dynamics is driven by a set of factors that evolve depending on complex environmental changes. A change in one of these factors downstream the supply chain is inevitably translated by an amplified one upstream. Called the Bullwhip effect, Lee et al. (1997) defines it as a phenomenon which "occurs when the demand order variability in the supply chain is amplified as they move up the supply chain". This effect provokes a lot of inefficiencies and unbalances within the supply chain and happens depending on several causes. Lee et al (1997) highlight four principal ones: demand signal processing or demand forecast updating, order batching, price fluctuation, and rationing and shortage gaming. Most researchers attribute the bullwhip effect to the irrational behavior of supply chain members. But as we can see in the literature, most research focuses more on the causes and the consequences of this effect and not much on factors that can generate these causes. So, this can also present an interesting future research direction. Also, researchers can focus on evaluating the influence of supply chain dynamics in other industries using the TOPSIS approach. Finally, we conclude by saying that both technical/economic and social logics have to be included in the cognitive map of a supply chain manager. We can hardly reach performance just by basing our decisions on technical/economic variables and elements. Supply chain performance is conditioned by social relationships that represent in the main its essence, in contrast to logistics, which focuses more on technical factors. Although, this can obviously be subject to discussion.

\section{Acknowledgement}

The authors extend their appreciation to the Deanship of Scientific Research at King Khalid University for funding this work through research groups program under grant number (G.R.P.2/176/42).

\section{References}

Anderson, J. C., \& Narus, J. A. (1990). A model of distributor firm and manufacturer firm working partnerships. Journal of Marketing, 54(1), 42-58.

Autry, C. W., Skinner, L. R., \& Lamb, C. W. (2008). Interorganizational citizenship behaviors: An empirical study. Journal of Business Logistics, 29(2), 53-74.

Benton, W. C., \& Maloni, M. (2005). The influence of power-driven buyer/seller relationships on supply chain satisfaction. Journal of operations management, 23(1), 1-22.

Blau, P. (1964). Power and exchange in social life. Wiley, NY.

Cox, A. (1999). Power, value and supply chain management. Supply Chain Management: An International Journal, 4(4), $167-175$.

Crozier, M. (1970). "La société bloquée”, Seuil, Paris,

Dahl, R. A. (1957). The concept of power. Behavioral Science, 2(3), 201-215.

Denzin, N. K., \& Lincoln, Y. S. (2008). Introduction: The discipline and practice of qualitative research.

Denzin, N. K., \& Lincoln, Y. S. (Eds.). (2011). The Sage handbook of qualitative research. sage.

Deutsch, M. (1969). Conflicts: Productive and destructive.

Dwyer, F. R., Schurr, P. H., \& Oh, S. (1987). Developing buyer-seller relationships. Journal of Marketing, 51(2), 11-27.

Emerson, R.M. (1976). Social Exchange Theory. Annual Review of Sociology, 2, 335-362.

Fawcett, S. E., Magnan, G. M., \& McCarter, M. W. (2008). A three-stage implementation model for supply chain collaboration. Journal of Business Logistics, 29(1), 93-112.

Flyvbjerg, B. (2011). Case Study. In Norman K. Denzin and Yvonna S. Lincoln, eds., The Sage Handbook of Qualitative Research, 4th Edition. Thousand Oaks, CA: Sage, pp. 301-316.

French, J. R., Raven, B., \& Cartwright, D. (1959). The bases of social power. Classics of organization theory, 7, 311-320.

Friedberg, E. (2009). Pouvoir et négociation. Négociations, 2, 15-22.

Gavirneni, S., Kapuscinski, R., \& Tayur, S. (1999). Value of information in capacitated supply chains. Management Science, 45(1), 16-24.

Griffith, D. A., Harvey, M. G., \& Lusch, R. F. (2006). Social exchange in supply chain relationships: The resulting benefits of procedural and distributive justice. Journal of Operations Management, 24(2), 85-98.

Guneshan R. and T.P Harrison. (1997). An introduction to supply chain management, Working Paper.

Handfield, R. B., \& Nichols, E. L. (2004). Key issues in global supply base management. Industrial Marketing Management, 33(1), 29-35.

Hocker, J., \& Wilmot Burton, W. (1985). Power in interpersonal conflict, Chapter three in Interpersonal Conflict.

Högberg, B. (2002). Trust and opportunism in supply chain relationships. In Proceedings of the 18th IMP Conference, Dijon, France.

Homans, G. C. (1961). Social Behavior: Its Elementary Forms, Harcourt, Brace and World. Inc., New York. 
Hunt, S. D., \& Nevin, J. R. (1974). Power in a channel of distribution: sources and consequences. Journal of Marketing Research, 11(2), 186-193.

Kambil, A., \& Short, J. E. (1994). Electronic integration and business network redesign: A roles-linkage perspective. Journal of Management Information Systems, 10(4), 59-83.

Klassen, R. D., \& Vereecke, A. (2012). Social issues in supply chains: Capabilities link responsibility, risk (opportunity), and performance. International Journal of Production Economics, 140(1), 103-115.

Kumar, K., \& Van Dissel, H. G. (1996). Sustainable collaboration: Managing conflict and cooperation in interorganizational systems. MIS quarterly, 20(3), 279-300.

Lambert, D. M., \& Cooper, M. C. (2000). Issues in supply chain management. Industrial Marketing Management, 29(1), 6583.

Lee, H. L., So, K. C., \& Tang, C. S. (2000). The value of information sharing in a two-level supply chain. Management Science, 46(5), 626-643.

Lee, H. L., Padmanabhan, V., \& Whang, S. (1997). Information distortion in a supply chain: The bullwhip effect. Management science, 43(4), 546-558.

Masterson, S. S., Lewis, K., Goldman, B. M., \& Taylor, M. S. (2000). Integrating justice and social exchange: The differing effects of fair procedures and treatment on work relationships. Academy of Management journal, 43(4), 738-748.

Mentzer J. T., DeWitt W., Keebler J. S., Min S., Nix N. W., Smith C. D. and Z.G. Zacharia, (2001). Defining supply chain management. Journal of Business Logistics, 22(2), 1-26.

Mohr, J., \& Spekman, R. (1994). Characteristics of partnership success: partnership attributes, communication behavior, and conflict resolution techniques. Strategic Management Journal, 15(2), 135-152.

Molm, L. D. (1997). Coercive power in social exchange. Cambridge University Press.

Morgan, R. M., \& Hunt, S. D. (1994). The commitment-trust theory of relationship marketing. Journal of Marketing, 58(3), 20-38.

Munson, C. L., Rosenblatt, M. J., \& Rosenblatt, Z. (1999). The use and abuse of power in supply chains. Business Horizons, 42(1), 55-56.

Patnayakuni, R., Rai, A., \& Seth, N. (2006). Relational antecedents of information flow integration for supply chain coordination. Journal of Management Information Systems, 23(1), 13-49.

Power, D. (2005). Supply chain management integration and implementation: a literature review. Supply chain management: an International Journal, 10(4), 252-263.

Chicksand, D. (2015). Partnerships: The role that power plays in shaping collaborative buyer-supplier exchanges. Industrial Marketing Management, 48, 121-139.

Cropanzano, R., Anthony, E. L., Daniels, S. R., \& Hall, A. V. (2017). Social exchange theory: A critical review with theoretical remedies. Academy of Management Annals, 11(1), 479-516.

Donohue, K., \& Schultz, K. (2019). The future is bright: Recent trends and emerging topics in behavioral operations.

Fahimnia, B., Pournader, M., Siemsen, E., Bendoly, E., \& Wang, C. (2019). Behavioral operations and supply chain management-a review and literature mapping. Decision Sciences, 50(6), 1127-1183.

Gölgeci, I., Murphy, W. H., \& Johnston, D. A. (2018). Power-based behaviors in supply chains and their effects on relational satisfaction: A fresh perspective and directions for research. European Management Journal, 36(2), 278-287.

Nakandala, D., Smith, M., \& Lau, H. (2020). Shared power and fairness in trust-based supply chain relationships in an urban local food system. British Food Journal.

Raven B.H., (1964). Social influence and power. University of California, Department of Psychology.

Samaddar, S., \& Kadiyala, S. S. (2006). An analysis of interorganizational resource sharing decisions in collaborative knowledge creation. European Journal of Operational Research, 170(1), 192-210.

Sarkar, A. (2013). A TOPSIS method to evaluate the technologies. International Journal of Quality \& Reliability Management, 31(1), 2-13.

Skinner, S. J., Gassenheimer, J. B., \& Kelley, S. W. (1992). Cooperation in supplier-dealer relations. Journal of Retailing, 68(2), 174-193.

Stake, R. E. (2006). Stake, Robert E., Multiple Case Study Analysis. New York: Guilford, 2006.

Coyote, B. L., \& Thompson, J. D. (1967). Organizations in action: Social science bases of administrative theory (Vol. 10). McGraw-Hill College.

Yawar, S. A., \& Seuring, S. (2019). A framework for managing social issues in supply chains. In Handbook on the Sustainable Supply Chain. Edward Elgar Publishing.

Zhou, H., \& Benton Jr, W. C. (2007). Supply chain practice and information sharing. Journal of Operations management, 25(6), 1348-1365.

Zouaghi, I., \& Spalanzani, A. (2009). Supply chains: ago-antagonistic systems through co-opetition game theory lens. in "Creating difference in Information era via value chains. 7th International Logistics and Supply Chain Congress, Yildiz Technical University and Logistics Association Publication, 6-7 November, Istanbul, Turkey, 2009. 
(C) 2022 by the authors; licensee Growing Science, Canada. This is an open access article distributed under the terms and conditions of the Creative Commons Attribution (CC-BY) license (http://creativecommons.org/licenses/by/4.0/). 